Journal of Community Based Environmental Engineering and Management, 2021, Vol. 5, No. 2: 111-116

\title{
REDESIGN LIVING PHARMACY PARK, KALI ANYAR VILLAGE, TAMBORA SUBDISTRICT, WEST JAKARTA
}

\author{
Retna Ayu Puspatarini*, Nabilah, Sri Handjajanti \\ Department of Architecture, Faculty of Civil Engineering and Planning, Universitas Trisakti, Indonesia
}

\begin{abstract}
Living Pharmacy Park in Sub village (SV) 007, Sub-sub village (SSV) 04, Kali Anyar Village, Tambora District located in West Jakarta is the location of Community Service activities. This activity was carried out gradually starting from before the Indonesian government issued a new order rule (New Normal) until the government issued new normal rules due to the Covid-19 pandemic. With the New Normal rules provide changes to the design of a living pharmacy park that has been designed before. This article aims to express the changes that occurred in the design of the living pharmacy park. The methods carried out are participatory methods and qualitative methods that are described descriptively. This article discusses the changing design sections that are adapted to the distance keeping rules. Redesign living pharmacy park is a work that combines design with the rules of New Normal covid 19.
\end{abstract}

Keywords: Living pharmacy park, New normal, Redesign

\section{Introduction}

Community service (CS) activities in the academic year 2020/2021 at Sub village (SV) 007, Sub-sub village (SSV) 04, Kali Anyar Village, Tambora District in West Jakarta is a series of multi-CS activities that began in the academic year 2019/2020. CS is currently carried out in 2 (two) stages, namely the design of the living pharmacy park and building a living pharmacy park. This article describes aspects of the redesign of the living pharmacy park carried out in CS.

Design is a word that consists of re and design. According to the Great Dictionary of Indonesian, redesign means a redesign. Another understanding conveys that design is an activity to change renewal so that it can meet positive

*Email: retna.ap@trisakti.ac.id

Received: 2 September 2021

Revised: 17 September 2021

Accepted: 17 September 2021

DOI: $10.23969 /$ jcbeem.v5i2.4538 goals for progress (Yusuf, R. D., Mutalib, W. A. 2021). Based on this understanding, the redesign in architecture is a redesign that is done because of changes that occur in the architecture. Related to this CS, the redesign carried out is to redesign the design of the living pharmacy park from the design image that has been produced in CS activities in 2019/2020. This change occurred due to something that affected the design.

In the previous CS activity produced an image of the design of a living pharmacy park that presents architectural elements in the form of stairs, arrangement of open space area barriers with regional roads, arrangement of chairs, sinks and water tanks, and where to lay plants. But recently with the Covid-19 pandemic in Indonesia, the government issued a new order rule (New Normal) for people to be able to carry out daily activities in the Covid-19 pandemic. The new order rules are to use masks, wash hands, and keep a distance (Kurniati, et al. 2021). With this new rule, the previous design image underwent changes in the design of the 
living pharmacy park. The change made is to apply the new order rules to the design of the living pharmacy park.

\section{Research Methodology}

The activity of redesigning the living pharmacy park is carried out using participatory methods. Participatory method is a method that involves the participation of parties related to the activities carried out (Aprianto, K.T. 2019 and Ardiansyah, M. 2016). Based on the understanding of participatory methods, in redesigning the living pharmacy park at SSV 04/SV 007, Kali Anyar Village, Tambora District in West Jakarta involves the surrounding community. The role of the community in CS activities so that the community has a sense of responsibility for the results of the draft that has been mutually agreed upon.

After being decided together with the aspects that affect the design image of the living pharmacy park, the next step is to describe the forms of changes made. To describe it is used qualitative methods that are described descriptively. The product of the design of the living pharmacy park is an architectural image. This depiction is done using computer software technology applications namely Autocad and Sketchup.

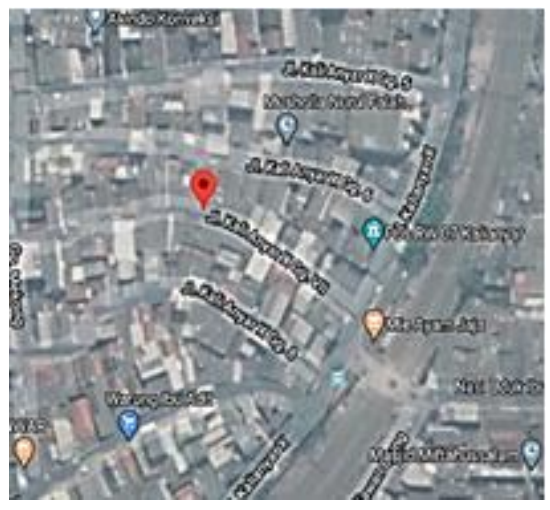

Figure 1. Kali Anyar Residents Map
This CS activity is on land owned by Kalianyar Residents who are on Kali Anyar X Road, $8^{\text {th }}$ street, SSV 04/RW.007, Kali Anyar Village, Tambora District, West Jakarta City, Jakarta Capital Special Region, post code: 11310.

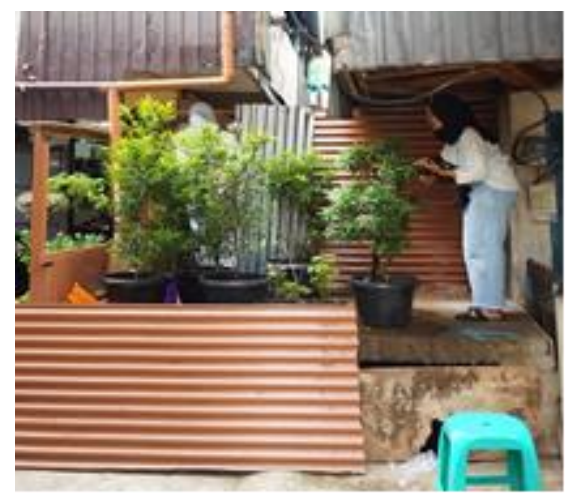

Figure 2. Front-looking Tread

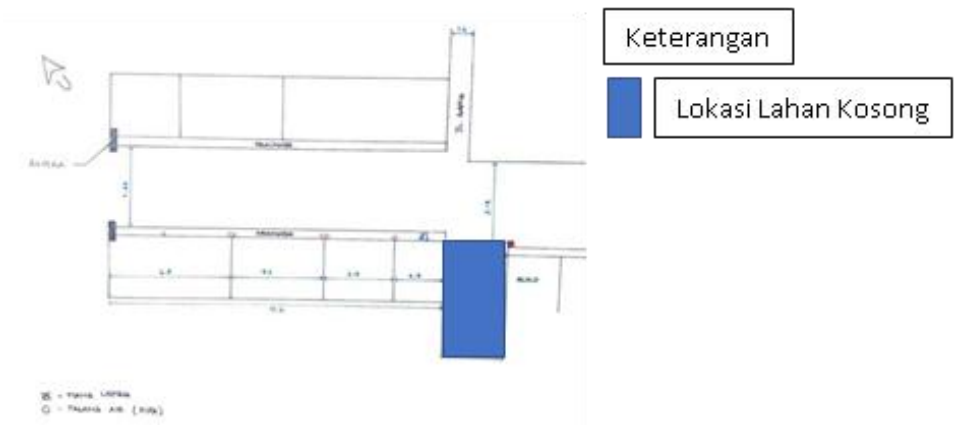

Figure 3. Location of vacant land in SSV 04/RW007

\section{Result and Discussion}

According to Shashi Caan (2011) in producing meaningful designs it is necessary to pay attention to the overall aspects that exist around humans. This not only pays attention to the physical aspects of humans but also pays attention to the experience and quality that surrounds it. Of course, these things are related to human relationship with their environment. Based on that, one form of the human environment that is currently happening in the world is a change in human lifestyle due to the Covid-19 pandemic announced by WHO (World Health Organization) on March $11^{\text {st }}, 2020$. For 
Ivan (2020), changes in human lifestyles present due to the Covid-19 pandemic show that these changes have a psychological and behavioral change in society.

Changes in lifestyle that occur due to the pandemic are known in the community as New Normal (new order rules). The rules that must be carried out by the community are to use masks, wash hands, and keep a distance. The appeal from the government that keep the distance between one person and another person is 1 meter. Related to maintaining this distance, in the design of architecture related to human space expressed by Edward T. Hall as proxemics. The space is divided into intimate space $(45 \mathrm{~cm})$, personal space $(45 \mathrm{~cm}-1.2 \mathrm{~m})$, social space $(1.2$ $\mathrm{m}-3.6 \mathrm{~m})$, and public space (3.6 m-7.6 meters) (Caan, S. 2011). Based on this understanding, the appeal delivered by the government to the community falls into the category of personal space of each individual community.

\section{Application of New Normal}

Based on the understanding related to the new order rules applied to reduce the spread of Covid-19, the design of a living pharmacy park also applies the New Normal rules. Therefore the design of the living pharmacy park are undergoes changes. New Normal regulations that affect the design of live pharmacy parks are hand washing and keeping a distance (social distancing).

Based on the results of field surveys in Tambora Residents and the application of New Normal to the results of design that have been made, there needs to be changes and design adjustments. These aspects will affect the use of green open areas and also affect user comfort. Here are some design readjustments to CS activities at SSV 04/SV 007 Kali Anyar Village, Tambora District, West Jakarta.
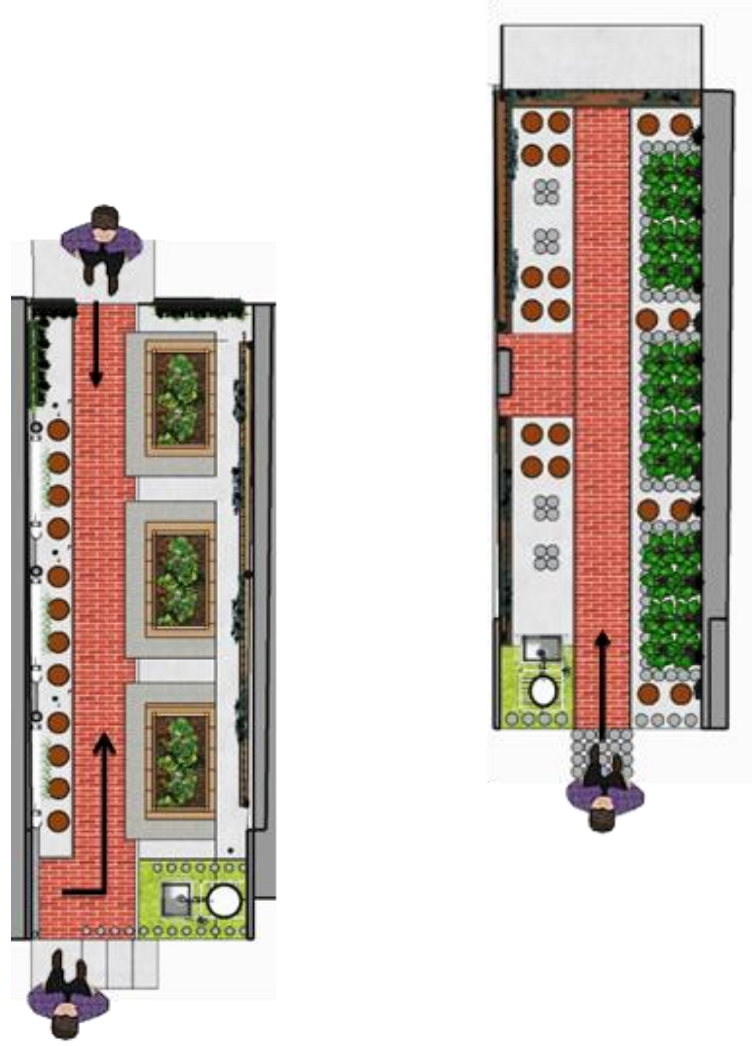

Figure 4. Old Layout Figure 5. New Layout

\section{Portable Sink Location}

In the initial design has been planned the portable sink to be used as a place to wash hands as well as watering plants in the green open area. This portable sink is placed in the front area of the tread where when the user enters the green open area will pass through the portable sink zone. The location in the front area is not changed because it has responded to the New Normal rules where when entering the living pharmacy park, the residents easily access the area for hand washing that is close to the entrance area to the park.
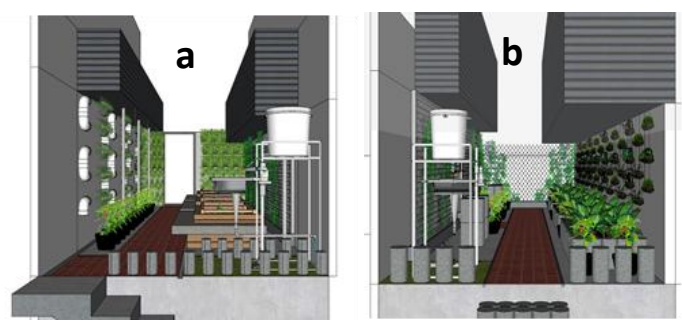
Figure 6. (a) Before (b) After the Location of Portable Sink

\section{Portable Sink Orientation}

Related to the new rules that apply the sink to wash hands, the design of the living pharmacy park from the beginning of the design has designed an area for hand washing. But there are differences that can be seen in the initial layout and the new layout, namely the location and direction of the roof of the hand washing facility. It looks like in figure 7.

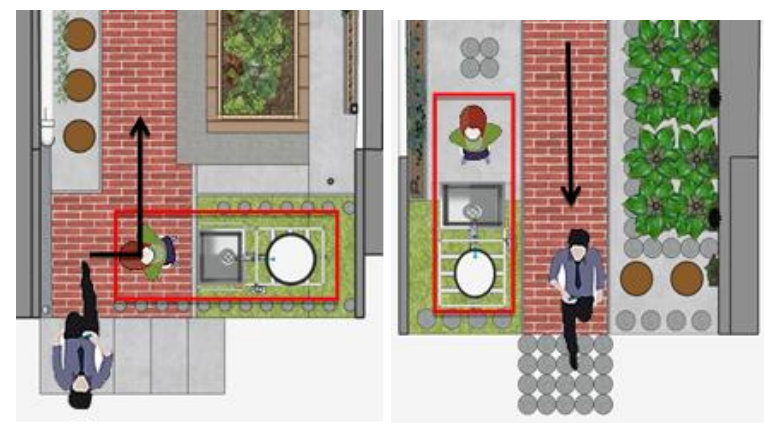

Figure 7. (a) Initial, (b) New Portable Sink Orientation

At the beginning of planning, the portable sink orientation leads to the west which means the room for the sink user stands on the west direction of the sink. This situation is difficult because the width of the site is only 2.5 meters which includes circulation that comes from the circulation of stairs and the circulation of users to the inner room, so that if the sink remains oriented to the west, when there are residents who are using the sink, other residents who just entered could not pass through it because circulation was blocked by residents who were using the sink. To anticipate these situation, the orientation of the portable sink is planned to go southwards to reduce the build-up of circulation at one point. The accumulation of circulation at one point does not support the new normal rule because it does not pay attention to the distance keeping rules applied to the design.

\section{Moving Seated Area on Site}

The area built for the Tambora Green Open Space area is only $15 \mathrm{~m}^{2}$, which in the initial design was formed the division of zones into two, namely circulation areas and plants areas. With the use of the plants areas made built in with the user's sitting and relaxing area. Made by making innovations in the shape of plant pots measuring $90 \mathrm{~cm} \times 195 \mathrm{~cm}$ and then there are plates on 3 sides of the pot approximately $30 \mathrm{~cm}$ that can be used as a seat. Because the tread room is quite narrow, the circulation path must still be made in accordance with the minimum standard of manufacture because for the convenience of the occupants, so that what can be done is to create an alternative design that can be multifunctional in one area.

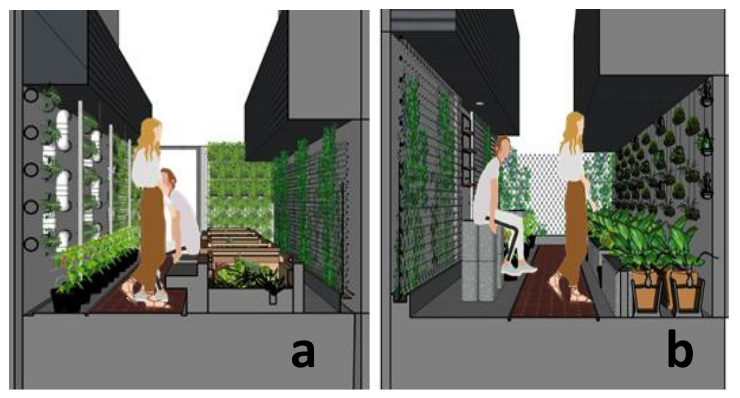

Figure 8. (a) Initial Layout, (b) New Layout of Seating and Watering zones

But the divide of zones as described above does not support the New Normal rules, so it needs to be changed. Made a seating design made of cylindrical concrete $15 \mathrm{~cm}$ in diameter with a height of $30 \mathrm{~cm}$ arranged 4 pieces to form a square. With the shape of such a chair will minimize the room for residents to sit. The zones is divided into 3 zones, namely right, center and left. The right zone as the plant area, the left for the plant and the sitting area, and the circulation path is in the middle. Continuous circulation path to the end of the tread. 


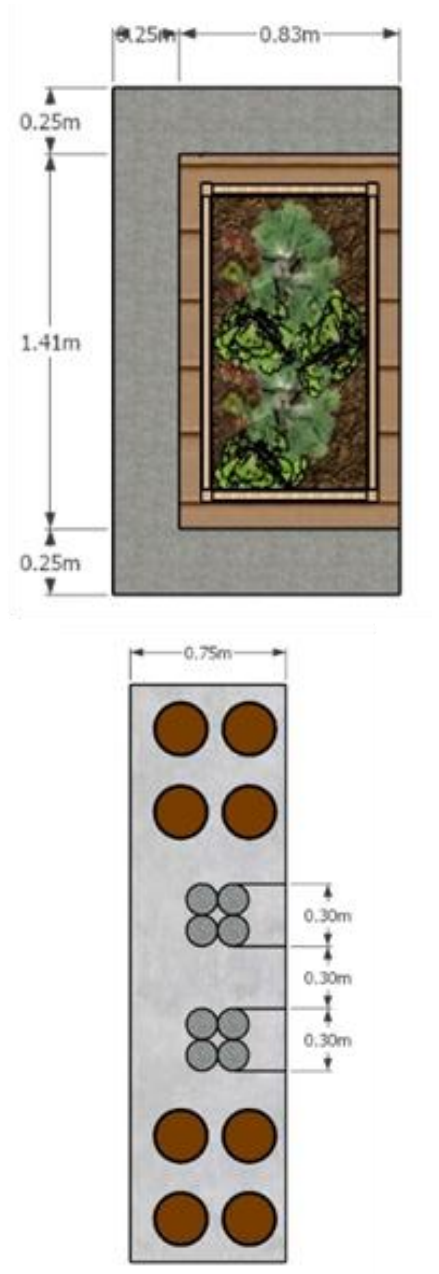

Figure 9. Initial Sitting Area Dimension
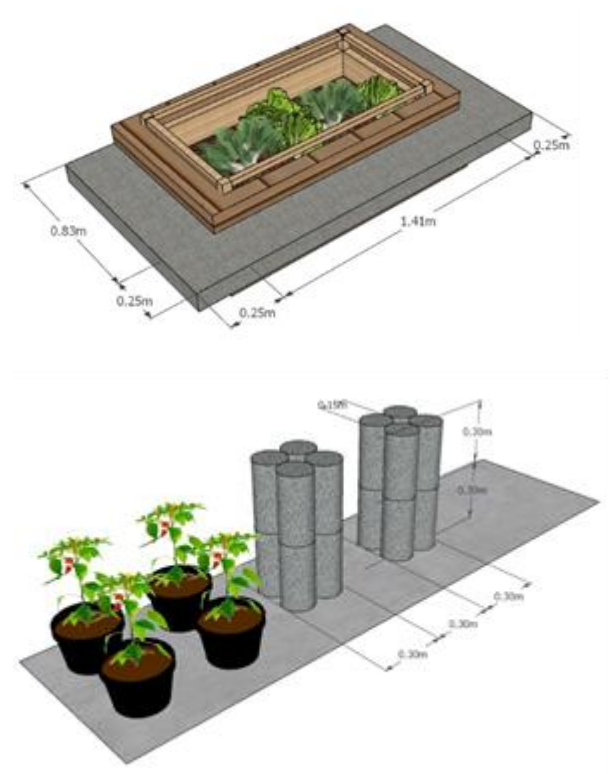

Figure 10. New Sitting Area Dimension

\section{Site Border Area for Security}

The security system in a resident becomes one aspect that needs to be considered to avoid things that are not desirable. In Tambora resident every neighborhood is connected by a road in the form of an alley. And the location of the site designed for Green Open Space on the border. So that initially designed by not giving a bulkhead at the end of the site that intersects with the next neighborhood to facilitate circulation between residents. However, the location around Tambora is quite secluded and must avoid open space is used improperly, so a barrier is needed to secure the area. The system used to provide bulkheads uses wire material. The selection of materials using wire serves as a barrier between areas but does not limit the visibility of humans or users as well so that the impression of green open space will remain wide.

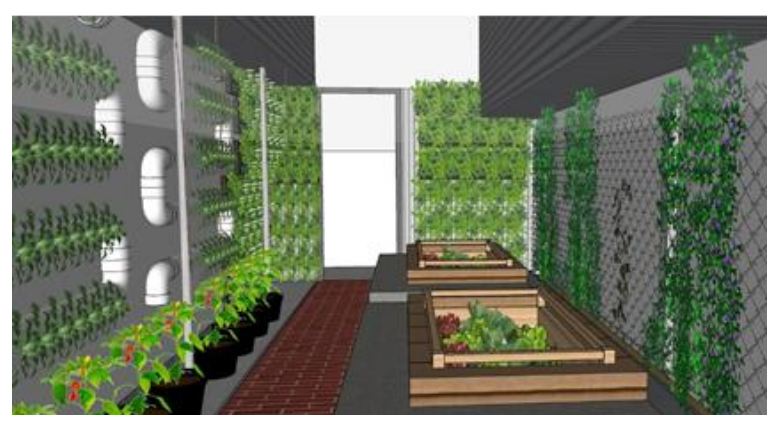

Figure 11. Initial Dividing Wall Material

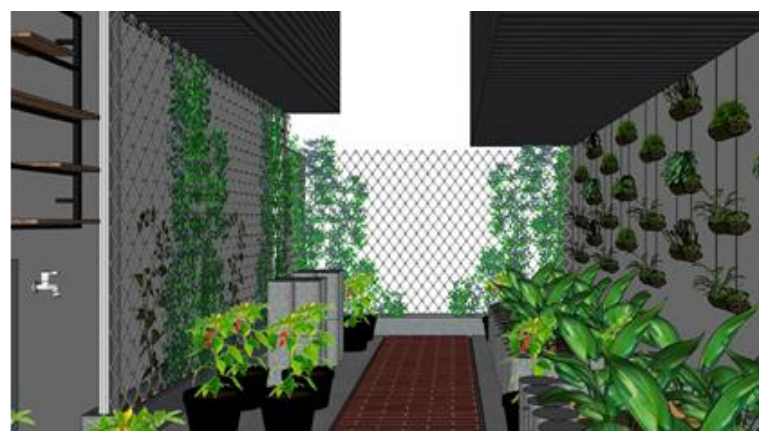

Figure 12. New Dividing Wall Material 


\section{Conclusion}

Based on the design process and the design results of Living Pharmacy Park in the SSV 04/SV 007 Tambora, West Jakarta can be concluded that the redesign process applied there are several things that have their own reasons, among others:

1. The position of the portable sink was originally on the right of the entrance area but the position inhibited the flow of circulation of space users and was not in accordance with the New Normal rules so that the position was changed to be on the left.

2. The orientation of the portable sink need to change to produce a wider and efficient space for the sink user and meet the New Normal rules.

3. The transfer of the seating area that was originally into one with the flower pot area was made separately. So there is a division of its own area, namely the seating area and the flower pot area. The sitting area is moved to the left area by paying attention to the distance of the seat in response to the policy of keeping distance (social distancing).

4. The site area bordering Hamlet 3 should not be a closed wall so the design changes are made by barriers using wire and do not provide doors in the border area. This method is done to limit people who enter the living pharmacy park so that easily controlled by residents who enter the site to avoid things that are not desirable. It is also to implement the New Normal policy of keeping a distance.

\section{References}

Aprianto, Kapit Tatak; Dkk. (2019). Pendampingan Partisipatori dalam Meningkatkan Kemandirian Masyarakat Tunagrahita.

Ardiansyah, M. (2016). Pengaruh Metode Partisipatori Terhadap Hasil Belajar Matematika. Jurnal SAP Vol.1 No.1 Agustus 2016

Agung, Ivan Muhammad. (2020). Memahami Pandemi COVID-19 dalam Perspektif Psikologi Sosial. Psikobuletin: Buletin Ilmiah Psikologi Vol. 1 No. 2 Mei 2020. 68-84

Caan, Shashi. (2011). Rethinking Design and Interiors: Human Beings in the Built Environment. Laurence King Publishing. London

Yusuf, Rais D. Hi; Mutalib, Wahyudin A. (2021). Redesain Pembangunan Gedung Perpustakaan Pusat Universitas Muhammadiyah Maluku Utara. DINTEK: Jurnal Teknik Vol. 14 No.1 Maret 2021. $72-78$

Kurniati, Nia; dkk. (2021). Edukasi Pencegahan Penyebaran Corona Virus Disease (COVID-19) Pada Tatanan Baru (New Normal) di Ruang Terbuka Hijau Pagutan Kota Mataram. E-Amal: Jurnal Pengabdian Kepada Masyarakat Vol. 01, No. 01, Januari 2021, 13-20. 